\title{
C.J.P. Niemandt
}

\section{TOGETHER TOWARDS NEW LIFE FOR MISSIOLOGY? MISSION AND MISSIOLOGY IN THE LIGHT OF THE WORLD COUNCIL OF CHURCHES 2013 POLICY STATEMENT}

\section{ABSTRACT}

Any meaningful discussion of the various understandings of mission and Missiology needs to take cognizance of the important policy document accepted by the World Council of Churches at its 10th Assembly in Busan, South-Korea, in October 2013: "Together towards life - mission and evangelism in changing landscapes". This is the first new mission affirmation by the WCC in 30 years, and presents a compelling new vision of Christian mission, namely its rootedness in God and its present role in the strengthening/consolidation/reinforcement of the reign of God. This research explores the relevance of the aforementioned policy document for mission and Missiology in terms of three themes: "Where do we come from?"; "What is happening now?", and "What could the future look like?"

\section{INTRODUCTION}

Any meaningful discussion on the various understandings of mission and Missiology needs to take cognizance of the important policy document accepted by the World Council of Churches (WCC) at its $10^{\text {th }}$ Assembly in Busan, South-Korea, in October 2013: "Together towards life - mission and evangelism in changing landscapes” (TTL) (Keum 2013). This research

Prof. C.J.P. Niemandt, Department of Science of Religion and Missiology, University of Pretoria, Pretoria, South Africa. E-mail:nelus.niemandt@up.ac.za 
explores the relevance of the policy document for mission and Missiology in terms of three themes: "Where do we come from?"; "What is happening now?", and "What could the future look like?"

Introduced to the WCC assembly on $4^{\text {th }}$ November 2013, TTL proposesin the words of Steve Bevans - "... a fresh, dynamic approach to engaging in the work of mission and evangelism in today's changing landscapes" (WCC 2013a). This is the first new mission affirmation by the WCC in 30 years - the previous official WCC position on mission and evangelism being "Mission and evangelism: An ecumenical affirmation", which was approved by the central committee in 1982 .

This new affirmation presents a persuasive new vision of Christian mission, its rootedness in God, and its present role in the strengthening and consolidation of the reign of God (Tveit 2013:vii). The new affirmation not only aims to provide new directions and concepts of mission for WCC member churches and affiliated mission bodies, but also seeks an appeal that is even wider than the WCC. As an ecumenical document, it plays the role of a mutual sharing of what God has given to the ecumenical community for the enrichment of all members, so that the broader community of Christians may join in with the Spirit and participate in God's mission.

But the TTL document cannot be read in isolation from another policy document also approved in Busan - "The church: Towards a common vision" (TC). The document's connection with, and relevance to Missiology - and its close relation to the TTL document - becomes clear in Tveit's description of the TC document:
an ambitious attempt to rethink what it means to be Christians together today. The work of two decades, it represents not only the first convergence statement in a generation; it also offers a theological vision of our life together as a communion that extends God's own mission in the world (Tveit 2013:vii).

The first chapter relates to the way in which the Christian community finds its origin in the mission of God, stating that "the church is essentially missionary" (WCC 2013b:6). Although the TC document is not the main focus of this research, its relevance will be briefly discussed in one of the subsections.

Bosch (1991:369; see also Kim 2009:23-27) noted the importance of world (ecumenical) missionary conferences in the understanding of mission, and Busan (2013) was to be no exception. If one looks back at the 1982 affirmation, it is clear that it was one of the most influential mission texts within the global missional movement of the past century (Keum 2012:1). The 2013 text promises to have a similar impact. Read together with the 
TC document, the two affirmations form a powerful missional statement on the identity of the church as missional by its very nature. If one takes a cue from the extensive study process and reflection on the Edinburgh 2010 event, the statements by the WCC have the potential to mould and enrich Missiology, bringing new life to Missiology and the academic reflection on mission.

The broad scope of the WCC and the large representation of churches from all over the world in the WCC suggest that TTL might have the potential to significantly influence theology and church praxis, as well as the future of Missiology. If the broad scope of the policy document is taken into account, it certainly warrants extensive missiological reflection.

\section{2. "TOGETHER TOWARDS LIFE" - A BRIEF HISTORY}

Following the $9^{\text {th }}$ Assembly of the WCC in Porto Alegre in 2006, the Commission on World Mission and Evangelism (CWME) decided to develop a new affirmation on mission and evangelism. Four work groups from the CWME and three WCC mission-related networks were engaged in a study process on the following themes:

- Transformative spirituality and mission;

- The "missional church", and "unity between church and mission";

- CWME Working Group on Evangelism and Unity on the issues surrounding "authentic evangelism, dialogue and prophecy";

- CWME Working Group on Health and Healing on "healing and wholeness for all";

- WCC Network of Just and Inclusive Communities on "mission from the margins";

1 See the publications by the Oxford Centre for Mission Studies by Regnum Books International. Edinburgh 2010 inspired a wide-ranging collaborative reflection on Christian mission, focused on the nine themes identified as being key to mission in the 21 st century. The study process was described as polycentric, open-ended, and as inclusive as possible of the different genders, regions of the world, and theological and confessional perspectives in today's church. The titles of the Edinburgh 2010 Series are divided into two categories: (1) the three official titles of Edinburgh 2010, and (2) publications of various study groups, including the Edinburgh 2010 main study groups, as well as the transversal, regional and different confessional study groups. The list of publications can be viewed at http://www.ocms.ac.uk/regnum/list.php?cat=3 
- the Ecumenical Network for Multicultural Ministry and Mission (ENFORMM) on "migration and multicultural churches", and

- the Oikotree Movement on "economic globalization and eco-justice" (Keum 2012:2).

The CWME finalised the document. The CWME Executive Group approved it in Geneva on 22 January 2012, and presented it to the CWME Pre-assembly Mission Event in Manila, 22-27 March 2012, after which it was significantly shortened and revised. "Together towards life - mission and evangelism in changing landscapes" was unanimously approved as an official statement of the WCC by its Central Committee at its meeting in Crete on 5 September 2012, presented at the $10^{\text {th }}$ Assembly of the WCC in Busan (Republic of Korea) in 2013, and received an enthusiastic response (see also Cruchley-Jones 2014:65).

\section{WHERE DO WE COME FROM?}

The document positions itself as a continuation of the many mission conferences of the International Missionary Council (IMC) and the Commission for World Mission and Evangelism (CWME) of the WCC. In this reflection, the furtherance of the ideas of Karl Barth, Lesslie Newbigin, Hans Hoekendijk and David Bosch in the TTL document will be discussed. The focus will not be on a description, or even summary of the ideas and words of these four giants as such, but rather on the TTL document. However, the following background information is important.

\subsection{Trinitarian origin and missio Dei}

Although Barth's impact and influence has been discussed in many books and articles, and although it might be nigh on impossible to describe his influence on Missiology in the scope of a single article, two intertwined ideas of Barth profoundly shaped Newbigin, Bosch and Missiology as discipline: his Trinitarian theology - specifically the relationship between his Trinitarian theology and the church, and Barth's groundwork that eventually led to the formulation of mission as the missio Dei - and the understanding that the missio Dei institutes the missio ecclesiae (Bosch 1991:370).

Barth has been credited with the Trinitarian renaissance and the renewed interest in Trinitarian theology (Leene 2013:19). Butin (1995:5) defines it as follows:

Since Barth's well-known step, there has been a growing acknowledgment in Reformed theology today - and indeed in theology in 
general - of the cruciality and indispensability of the doctrine of the Trinity as the paradigm of God's relationship with humanity.

For Barth, one of the most important tasks of theology was to clarify the reflection on the relationship between God and humanity; the Trinity provided the most appropriate framework within which to formulate this relationship. Much later, Moltmann (2010:162) articulated it in a very powerful way:

The church does not only correspond to the unity of the Triune God, it also finds its living space in the Triune God.

Barth's groundwork on God's mission began at the 1932 Brandenburg Missionary Conference, when he defined mission as "an activity of God himself" (Bosch 1991:399). Barth understood mission as an activity at the very heart of the triune God (Kim 2009:28). The profound implication of this idea was that it placed the origin and initiative of mission in God and not in the church. The church is missionary, empowered by the Holy Spirit, participating in God's mission, and its focus is on all of creation (Kim 2009:28-29). At the IMC in Willingen (1952), Karl Hartenstein developed Barth's foundation of Trinitarian mission, stating that mission occurred within the triune God's overall plan for salvation, because "God is mission" (Bevans \& Schroeder 2011:57). Willingen became known for understanding mission as originating in, and flowing from the nature of the Triune God (Bosch 1991:399; Flett 2010:11), and the conviction that witness is not something optional, but integral to the life of the whole church (Kim 2009:25). Thus the shift was from being church-centred to seeing the church becoming mission-centred (Bosch 1991:379).

It is important to bear in mind Flett's (2010:12) observation that Barth's contemporaries did not view Barth as a friend of mission. However, Barth's Trinitarian emphasis has influenced a wider circle of theological development on the centre of mission: it originated as God's activity rather than the human activity of the church.

\subsection{Missio Dei}

The concept missio Dei acknowledges that the church is, by nature, missionary. The term itself gained wide acceptance after 1964, when Georg Vicedom used it in his book The Mission of God, and the Second Vatican Council ${ }^{2}$ spoke of the church as "missionary by its very nature". The ownership of mission is entirely with God from start to finish (Bosch 1991:482). The Father sends the Son, and together they send the

2 Decree on mission activity, paragraph 2. 
Holy Spirit (Wright 2006:63). The role of human beings (i.e., the church) is to be the instruments that God employs to conduct his mission (Van Gelder \& Zscheile 2011:30). Missio Dei begins from the realization that mission belongs to God and is first and foremost God's initiative, an initiative in which the church is asked/allowed to participate (Kim 2011:259).

In advances after Willingen, two foci can be observed (Van Gelder \& Zscheile 2011:30): "redemption" that is "specialized" through the church's role as the principle channel whereby God's redemption occurs in the world, and "creation" that has a broader perspective of God's desire to continue to care for his creation. Hoekendijk, who became well known for his support of the latter position, was concerned about mission's overemphasis on church growth, and argued that mission focused only on the church stands in juxtaposition to mission focused on the kingdom of God. He argued that the world, not the church, is the core of God's mission. For him, the church is never the subject of mission; at most it is a partner in the missio Dei (see also Flett 2010:44). This leads to an "apostolate theology", where the church is perceived primarily in its relationship with the world. The gospel and the apostolate belong together in the sense that God continues to struggle for the world for the sake of the world (Flett 2010:52). For Hoekendijk, shalom was the guiding principle - it describes the true objective of the church's work in the present (Skreslet 2012:/oc. 816).

A key figure influencing the understanding of the missio Dei was Lesslie Newbigin and his Trinitarian emphasis. He stated that mission was "proclaiming the kingdom of the Father ... sharing the life of the Son, and ... bearing witness of the Spirit" (Newbigin 1995:29). The church proclaims "the reign of God" (i.e., the kingdom of God) "over all things", because the church believes that God is ruler over all. The church "acts out the love of Jesus that took him to the cross" when it invites people into a union with Jesus Christ who is "the presence of the kingdom" in the world. The Holy Spirit as the "preview" of God's kingdom directs the church into the world, often in mysterious ways (Newbigin 1995:65).

Bosch's contribution to the definition of missio Dei cannot be underestimated. His Transforming Mission has been described as a magnificent charting of the missio Dei (Kim 2011:259). Bosch (1991:402) observes that mission originates only from the heart of the Triune God who acts as a "fountain of sending love". Mission belongs to God and is first and foremost God's initiative. The meaning of mission is found in the relationship within the Trinity expressed in this progression: 
The Father sends the Son, the Father and the Son send the Holy Spirit. The Father, Son and Holy Spirit send the church into the world (Bosch 1991:399).

The church is missionary, because it exists to be sent for God's mission.

\section{WHAT IS HAPPENING NOW?}

This section explores developments in the TTL document, as well as the close connection between the TTL document and the WCC Faith and Order convergence statement on "The church: Towards a common vision" (TC) (WCC 2013b).

When studying the 2013 affirmation "Together towards life", it is not difficult to note the influence of both previous ecumenical meetings, and the theologies of Barth, Hoekendijk, Newbigin and Bosch, specifically, on the document.

\subsection{Trinitarian foundation}

The Trinitarian foundation is stated in the very first words: "We believe in the Triune God who is the creator, redeemer and sustainer of all life" (Keum 2013:4). This is followed by

Mission begins in the heart of the Triune God and the love which binds together the Holy Trinity overflows to all humanity and creation (Keum 2013: 4).

In paragraph 19, it is reiterated that mission is the overflow of the infinite love of the Triune God (Keum 2013:9). This Trinitarian grounding is also evident in the TC: "The origin of the Church is rooted in the plan of the Triune God for humankind's salvation" (WCC 2013b:9).

\subsection{Missio Dei}

The missio Dei concept shifted previously held understandings of the origin and source of mission from human to divine agency (Laing 2011:223). The TTL document describes the missio Dei in paragraph 43:

God's mission points to the belief in God as One who acts in history and in creation, in concrete realities of time and contexts, who seeks the fullness of life for the whole earth through justice, peace and reconciliation (Keum 2013:17). 
The theological concept of missio Dei was redefined and expanded along the lines that mission is "finding out where the Holy Spirit is at work and joining in" (Kim 2011:263) - i.e., that the key role of the Holy Spirit within the mission of the Triune God is now emphasized. TTL states that the essence of mission is a life in the Holy Spirit (Keum 2013:4). This affirmation makes a clear association between the overarching issue of "life in fullness" and the work and presence of the Holy Spirit in creation and the church: "The powerful presence of the Holy Spirit, revealed in Jesus Christ, the crucified and risen Lord, initiates us into the fullness of life that is God's gift to each one of us" (Keum 2013:21). An entire section is devoted to "The Mission of the Spirit" (paragraphs 12-18):

- The Spirit is the source of life and the breath of humankind - "... the universality of the Spirit's economy in creation ..." (Keum 2013:8).

- The role of the Spirit in the life and ministry of Jesus Christ.

- The Spirit as gift to the church.

- The particularity of the Spirit's work in redemption.

- The role of the Spirit in mission.

The section concludes that, through the Spirit, we participate in the mission of love that is at the heart of the life of the Trinity (Keum 2013:9). This argument is again taken up in the summary of the TTL document, where a number of affirmations are stated:

We affirm that mission begins with God's act of creation and continues in re-creation, by the enlivening power of the Holy Spirit (Keum 2013:37).

Keum (2012:3) also notes that this

new ecumenical affirmation focuses on the mission of the Holy Spirit (missio Spiritus) as its theological framework within the Trinitarian understanding of mission (missio Dei). This with the intention to embrace dynamism, transformation and diversity as the main concepts of mission in changing landscapes today.

Mæland (2013:140) mentions that this emphasis on missio Spiritus

reflects important theological developments from denominational as well as ecumenical sources, as well as important post-colonial and post-Western insights, certainly in line with what has become rather commonplace in academic missiology. 
Cruchley-Jones (2014:64) observes that TTL celebrates how the Spirit empowers and acts with, and through all people, and that the Spirit gathers up all of creation, all life, into God's mission. This shift in missiology is part of a larger theological turn towards pneumatology, especially due to the influence of the pneuma-praxis of Pentecostal and Charismatic movements (Wild-Wood 2013:46). The emphasis on the work of the Holy Spirit can also be understood as a way to reach out to the Orthodox family in the WCC indeed an ecumenical formulation!

The same is evident when one considers the following statement in the TC document (WCC 2013b:9):

The Holy Spirit came upon the disciples on the morning of Pentecost for the purpose of equipping them to begin the mission entrusted to them (cf. Ac 2:1-41). God's plan to save the world (sometimes referred to with the Latin expression missio Dei or 'the mission of God') is carried out through the sending of the Son and the Holy Spirit.

The church acts by the power of the Spirit to continue the Spirit's lifegiving mission, so participating in the work of God to heal a broken world (WCC 2013b:8).

The question that needs to be answered is whether the TTL and TC documents serve as a correction of what Niles (2012:274) described as a "processional description" of the Trinity. He refers to Bosch's (1991:390) description of the missio Dei (i.e., "God the Father sending the Son, and God the Father and the Son sending the Holy Spirit, expanded to include yet another 'movement': Father, Son and Spirit sending the church into the world"). Niles critiques the absence of the idea that each person of the Trinity has equal weight and value and can work independently from each other, although consistent with each other:

In this theology, the first person of the Trinity is given primacy only in
being wholly other and unknown. Moreover, the first person can only
be known through Christ, the second person in the Trinity. In turn,
these two determine the activity of the third person, the Holy Spirit
(Niles 2012:274).

The discussion of the pneumatological focus of the TTL document mentioned earlier partially answers Niles' challenge, in the sense that the way in which the TTL document formulates the activity of the Spirit deconstructs the "processional" approach of Bosch and others. The introductory paragraph (Keum 2013:4) was also carefully drafted to succeed in balancing the involvement of each person in the Trinity in the gift of life (God created life and "works in the world to affirm and safeguard life"; Christ is the Life of the world and "affirms life in its fullness", and the 
Holy Spirit is the Life-giver "who sustains and empowers life and renews the whole creation"). Unfortunately, the TC document (WCC 2013b:9) still refers to the rather "flat" understanding of missio Dei as God's plan to save the world "through the sending of the Son and the Holy Spirit". The conclusion of the TTL document (Keum 2013:40) does seem to solve Niles' critique:

\begin{abstract}
The Triune God invites the whole creation to the Feast of Life, through Jesus Christ who came 'that they may have life, and may have it in all its fullness' (Jn 10:10, REB), through the Holy Spirit who affirms the vision of the reign of God, 'Behold, I create new heaven and a new earth!' (Is 65:17, KJV). We commit ourselves together in humility and hope to the mission of God, who recreates all and reconciles all. And we pray, 'God of Life, lead us into justice and peace!'
\end{abstract}

\title{
4.3 Discernment
}

The emergence of the issue of discernment can be understood from the conviction about the importance of contextualization and the indigenization of God's word. The contextual reception of Scripture is a key feature of how God makes himself known to human beings. Billings (2010:loc. 1463) states that,

in a similar way as the Word became flesh and inhabited a human culture in Jesus Christ, God's word is received in a culture when it comes to inhabit that culture by the Spirit's indwelling power.

The Spirit works to indigenize God's word in various contexts and cultures; therefore, Christians should engage in the task of spiritual discernment, seeking to discern

... a particular shape of the Spirit's spacious yet bounded work in using

Scripture to transform the church even deeper into Christ's image.

Kim (2009:34) calls discernment the first act of mission.

The Spirit enables the reception of Christian faith in a way that makes the gospel a living message in various cultural contexts (Billings 2010:/oc. 1503).

The Holy Spirit is the Spirit of discernment, who reveals God's will to us in, and through cultures (Kim 2009:45).

The TTL document recognizes discernment as one of the important gifts of the Spirit. The introductory paragraph (Keum 2013:4) asks: "How and where do we discern God's life-giving work that enables us to 
participate in God's mission today?" Discernment is the core practice of a missional church - seeking the presence or movement of the Triune God in relationship with all of creation (Niemandt 2012:6). Discernment is the first and most decisive step on this missional journey. It is a core practice of Christian leadership and spirituality. Discernment is indispensable to be able to live in God's mission for the sake of the world, and to be able to imagine God's future for this world. Discerning the Spirit or spirits is a complex process, but Keifert (2009:21) clarifies discernment as a process of attending to three sources for spiritual discernment: tradition, especially Scripture; culture and society, and the personal and communal experience of the faithful. In each of these, the questions are: "What is God up to here?" and "What is the word of God for us in this place and time?"

TC (WCC 2013b:18) focuses on the fact that the Church is not merely the sum of its individual believers among themselves. The Church is fundamentally a communion in the Triune God and, at the same time, a communion whose members partake together in the life and mission of God. This means that discernment is a relational issue, done in communion with others, and in mutual love and dialogue. The TC document (WCC 2013b:41) invites churches to discern together:

How might the churches, guided by the Spirit, discern together what it means today to understand and live in fidelity to the teaching and attitude of Jesus? How can the churches, as they engage together in this task of discernment, offer appropriate models of discourse and wise counsel to the societies in which they are called to serve?

TTL (Keum 2013:11) states:

The churches are called to discern the work of the life-giving Spirit sent into the world and to join with the Holy Spirit in bringing about God's reign of justice (Ac 1:6-8). When we have discerned the Holy Spirit's presence, we are called to respond.

The WCC was cautious in its formulation of discernment, and put it in the context of an encounter with the Triune God. Kim (2009:36) remarked that we seek Christ-likeness when we identify where the Spirit is at work in order to join God's mission. Bevans (2014:33), referring to Pope John Paul II and former Archbishop of Canterbury Rowan Williams, introduced TTL with the following remark:

The Spirit is the principal agent of mission. Mission is finding out where the Spirit is working, and joining in. 
This is echoed in the concluding affirmation of the TTL document: we are called to discern the Spirit of God wherever there is life in its fullness (Keum 2013:37).

\subsection{The church and mission}

Since the critique by Hoekendijk on ecclesiocentrism in mission theology (Skreslet 2012:/oc. 1731), and given his influence in ecumenical meetings, the relationship between church and mission has been a point of contention and intense discussion. For Hoekendijk, the world - not the church - is the centre of God's mission.

TTL addresses the relationship between church and mission, stating that it "... is not the church that has a mission but rather the mission that has a church" (Keum 2013:63). It can be said that the statement in TTL that mission is not a project of expanding churches but of the church embodying God's salvation in this world (Keum 2013:63) echoes Hoekendijk's critique and represents a new approach that did not begin with the church and its standard missionary agenda (Skreslet 2012:/oc. 1748). It is significant that TTL (Keum 2013:63) starts with a declaration that the "life of the church arises from the love of the Triune God". If read with the next statement - that mission is a response to "God's urging love shown in creation and redemption" - it becomes clear that the point of departure is God himself.

This is also the case with TC, which regards the church as rooted in the vision of God's great design for all creation - the kingdom (WCC 2013b:8). The church has an evangelistic vocation to proclaim the kingdom, and this includes the transformation of the world towards the kingdom of God. The church is sign and servant of God's design (WCC 2013b:18-19).

This positioning of mission in the Trinity, the emphasis on the activity of the Holy Spirit, and the understanding of mission as life-giving, together with the focus on justice and people in the margins (see Ross et al. 2014:15) succeed in solving a tension that has been apparent since the critique of Hoekendijk at Uppsala, by placing divine action alongside human agency. It might be that the influence of Hoekendijk still leads to a "softer" formulation of the role of the church in mission in TTL, and perhaps an underplaying of the centrality of the church to mission. In the case of TC, the central place of the church in the mission of God, and as a continuation of God's mission, is discussed in much clearer terms. 


\section{WHAT COULD THE FUTURE LOOK LIKE?}

The very act of reflecting on an ecumenical document reminds us that we are collectively engaged in the missio Dei through the strength of the Spirit, and that we are doing it within diverse contexts.

This section concludes with a number of observations on exciting new possibilities for mission and Missiology, as revealed by "Together towards life". It discusses possible future themes such as missions with creation at its heart; missional ecclesiology and missional leadership; mission supported by a "transformative spirituality", and mission from the margins.

\subsection{Mission with creation at its heart}

The TTL document very clearly focuses on the relationship with creation and life in all its fullness. The introduction of the theme clarifies the scope and intention of TTL (Keum 2013:4):

God invites us into the life-giving mission of the Triune God and empowers us to bear witness to the vision of abundant life for all in the new heaven and earth.

It also mentions that "the church is commissioned to celebrate life, and to resist and transform all life-destroying forces" (Keum 2013:4). Noordt (2013:194) correctly observes that "the emphasis on life-affirming mission is of crucial significance for TTL". The mission statement claims that the Spirit of God is at work where life is affirmed and blossoms. As such, the affirmation of life is a criterion to be able to distinguish between the spirits of this world and the Spirit of God, serving as an instrument to observe where God's Spirit is at work. The affirmation thereby also establishes a theological bridge between the Christian faith, secular world views, indigenous religions, and wisdom traditions - for, because the gospel is good news for all of creation, it is vital to recognize God's mission in a cosmic sense, and to affirm all life, the whole oikoumene, as being interconnected in God's web of life (Keum 2013:5). This also represents an important point of critique on TTL: the hermeneutical key, namely that the Spirit is at work where life is affirmed and blossoms, begs the question of how this is reconciled with the classic point of view that the Spirit always points towards Jesus the Christ. ${ }^{3}$

A whole section is dedicated to the subtheme of "Mission and the flourishing of creation". This section describes the relation between the

3 See, for example, the Lausanne Movement (2011:10) and the Cape Town declaration. 
missionary God, creation of life and the church's calling to participate in God's life-giving mission. The following issues can be identified:

- The fact that God's mission begins with the act of creation (Keum 2013:9). This serves as a correction for the human-centered view of creation and affirms a spiritual connection with creation.

- The holistic approach to mission with a focus on life and the cosmic implications of the gospel. As Keum (2012:2) puts it, "mission is understood beyond anthropocentric goals". Mission includes the earth and the whole of creation.

- The departure from an exclusively anthropocentric approach means that mission is not something done by humanity to others, but in communion with all of creation (Keum 2013:10).

- A recognition of the importance of eco-justice.

Langerak (2011:197) describes the future of Missiology as a movement towards an eco-ecumenical theology. She critiqued the San Antonio conference on world mission, stating that there was little development of an incarnational view that would see the Triune God as suffering with, moving with, and empowering the universe. Notwithstanding this critique, her summary of San Antonio as a clear, very promising step toward an eco-ecumenical theology is equally appropriate for the TTL document. Cruchley-Jones (2014:64) describes TTL as the first ecumenical affirmation where creation is recognised as a partner in God's mission and not only an object of mission.

The significance of "mission with creation at its heart" is that mission in God's way extends to God's creation, and that participating in lifegiving mission is a crucial part of the church's mission. This entails, at the very least, missiological reflection on appropriate lifestyles and practices as part of Christian mission, and means that eco-justice becomes fundamental to mission. The economic solution has moved to the centre of the stage. One of the significant effects is that poverty and affluence have diametrically grown beyond all expectations. The problem is a destructive consumerism, driving people apart. This calls for a serious reflection from the ecumenical community and creative ideas on appropriate lifestyles and practices. My colleague, Attie van Niekerk (Van Niekerk 2014:412), asks the following question:

How do we, both rich and poor, start to transform our lifestyles towards a better ethical quality of life, as the people of God in this context? 
He proposes that Missiology keep itself busy with a Christian description of an ethical quality of life that may be characterized by good relations, fairness to all, promoting the lives of others and of God's creation, and promoting dignity (Van Niekerk 2014:415). It is a very complex and concrete task to put this moral vision into practice: to develop new relations to each other and to the material world. It requires a new vision of what happiness is, and it requires resources, knowledge, skills, funding, and partnerships (Van Niekerk 2014:417). It reminds me of Kim's (2009:66) remark that "mission is not only about changing the church, but also about changing society".

\subsection{Missional ecclesiology and missional leadership}

The church is the mission. The ecumenical discourse of the past century recovered the relationship between mission and church (Laing 2011:225). Missional ecclesiology is grounded in the missio Trinitatis. The TTL document states that it is impossible to separate church and mission. The church originated as part of God's mission and the aim of the church is to fulfil God's missionary purpose.

The relationship between church and mission is very intimate because the same Spirit of Christ who empowers the church in mission is also the life of the church (TTL - Keum 2013:21).

The church is a sign and symbol of the reign of God, as it witnesses to the power of Christ through the transforming work of the Holy Spirit. Thus, mission is holistic, because it focuses on all of life and all of creation as it calls people to "abundant life" (Bevans \& Schroeder 2004:302). Woods (2014:78) also understands local congregations as the interface between the celebration and nurturing of our faith and our witness to the world. This aspect is even more evident in the TC document. It places the church within the mission of God, and the core identity of the church is its missional identity. The church plays an important role in the design of God (WCC 2013b:8). TC (WCC 2013b:13) also states that the

Church is centred and grounded in the Gospel, the proclamation of the Incarnate Word, Jesus Christ, Son of the Father.

Mission is contextual. It is important to grasp the implications of the concept of missio Dei, as it gives local churches the freedom to develop their own interpretation of the will of God and to discern what the Spirit is up to. This means that "mission is understood and practised according to local conditions" (Kim 2011:259). The focus in missional ecclesiology is on local 
congregations. The missional church is a local church (Niemandt 2012:7). It is a community that has been

... called, gathered and equipped by the Spirit and sent to participate in God's mission by bringing the Gospel of God's love and new life (Niemandt 2012:2)

to a particular place and time. This means that a missional ecclesiology sees the church existing "... first and foremost on the level of a local community" (Niemandt 2012:7), where it is to be a life-affirming community, and a sign and symbol of the reign of God.

The emphasis on local congregations is clear. The TTL document (Keum 2013:26) mentions that it is important to honour the way in which each local congregation is led by the Spirit to respond to its own contextual realities: "Today's changed world calls for local congregations to take new initiatives". Networks such as The South African Partnership for Missional Churches and expressions such as Fresh Expressions and emerging churches serve as case studies and examples of localized contextualization and new initiatives. One of the important aspects of this new understanding of mission is its emphasis on the missio Dei in the public arena. The church should find out what God is doing in the world outside its walls and get involved there. One of the important tasks of Missiology will then be to reflect on creative, contextual expressions of church in each and every context.

The church does what it is. The church organizes what it does. The ministry of the church introduces strategies and processes that require the exercise of leadership (Van Gelder 2007:18). The church needs an appropriate missional understanding of leadership in order to organize and transform the church into missional life and to participate in the transformation of communities to share life in its fullness. The TTL document refers to the need for a new understanding of mission and evangelism because of the manifold changes in our landscape. This also raises the issues of missional leadership to succeed in the formation of a missional congregational culture; the transformation of a traditional congregational culture into a missional congregational culture is a complex process that involves deep-rooted cultural shifts. "Unless the paradigm at the heart of the culture is changed, there can be no lasting change" (Hirsch 2006:54). Ross et al. (2014:15) plead with the church's institutions for training and formation to give urgent priority to reviewing the undergirding theologies of leadership that inform their missional understanding and praxis.

The statement in TC (WCC 2013b:15) is especially relevant: "the Church has never been without persons holding specific authority and 
responsibility", noting that, "Jesus chose and sent the disciples to be witnesses of the kingdom". The mission which Jesus entrusted to the eleven in Matthew 28 entails

a ministry of word, sacrament and oversight given by Christ to the Church to be carried out by some of its members for the good of all (WCC 2013b: 15).

\subsection{Mission supported by a "transformative spirituality"}

The church, sent in the Spirit to engage in the missio Dei, seeks to be the "fellowship of the Spirit". Mission is a spiritual endeavour, and spiritual life is missional, since both are human responses to impulses produced by the mission of the Spirit throughout the whole of creation. Spirituality is the heart of mission praxis (Kritzinger \& Saayman 2011:189). Bosch (1979:13) gave his own description of spirituality:

'Flesh' and 'spirit' in the Bible do not refer to two segments of our lives, the one outward and worldly, the other inward and otherworldly, as though we are spiritual when we pray and worldly when we work. No, flesh and spirit refer to two modes of existence, two lifeorientations. Being spiritual means being in Christ, whether we pray or walk or work.

According to Bosch (1979:13), "spirituality is not contemplation over against action, and it does not entail a flight from the world over against involvement in the world". Rather the very opposite - the involvement in this world should lead to a deepening of our relationship with, and dependence on God. A deeper relationship with God also leads to increasing involvement in the world.

Doornenbal's (2012:212) description is to the point: "missional spirituality is a spirituality that forms and feeds mission". TTL (Keum 2013:12-13, 74) acknowledges the importance of a spirituality rooted in the life of the Trinity. Spirituality is the source of energy for mission and is transformative; it transforms the church, as well as the communities in which the church finds itself. It states (Keum 2013:13):

Mission spirituality resists and seeks to transform all life-destroying values and systems wherever these are at work in our economies, our politics, and even our churches.

The relationship between mission, spirituality and creation is firmly established and "woven together for they are mutually transformative" (Keum 2013:74). 
Although one would expect at least a reference to spirituality in general in the TC document, the document is strangely silent on this issue. Matthey (2010:254) mentions that spirituality must inspire pragmatic solutions and real-life habits for churches. It must lead to discovering God's presence and wisdom in, and advice for concrete and real-life situations. Ross et al. (2014:10) call for the overthrow of

... the rogue spirit of greed that provides the energy to lubricate a market that enslaves those who live on the margins.

\subsection{Mission from the margins}

I conclude with the future opportunities presented by the focus of the TTL document on mission from the margins.

Edinburgh 2010 (Balia \& Kim 2010:177) drew attention to the importance of marginalized communities. The editorial of a recent Mission Studies (Kim 2013:6) mentions that marginalization is a key mission topic. The acknowledgement of mission from the margins serves as a counterpoint to injustices in life, church and mission (Keum 2013:15). Jesus Christ embraces the marginalized. Jesus is in the margins (McKinnley 2005:27). This implies that mission, participating in Christ's mission, can be done by the powerless to the powerful, the poor to the rich, and the marginalized to the privileged. TTL (Keum 2013:39) argues that "[t]he marginalized in society are the main partners in God's mission". The church must pay careful attention to the marginalized, as solidarity with (and inclusion of) the marginalized are key expressions of mission. Meylahn $(2012: 13,61)$ makes the point that the marginalized crack open dominant discourses, and show the discrepancies and wounds of the dominant common language. The missional church identifies and proclaims Christ and the cross in these cracks. In this process, the story of Christ's incarnation is proclaimed through the church's identification with the marginalized.

The kingdom to come breaks open any story with the question: what have you done for the least of my brothers and sisters (Mt 25)? (Meylahn 2013:63).

We need a theology of the poor and marginalized. It is a fundamental task of the church's mission to break down the walls that divide, dehumanize, discriminate, alienate, exclude, and marginalize. The walls are broken down where the church listens and discerns, receives the marginalized and allows their stories to crack open the dominant discourses. Edinburgh 2010 (Balia \& Kim 2010:191) spoke about the dynamics of mission as both "sending" and "receiving" and "reverse mission dynamics". Meylahn (2012:37) argues 
that the church needs the marginalized, for they show the church the cracks and wounds in its context, and these cracks and wounds are the very places for revelation and creativity where fresh expressions of church can break through.

God is at the margins, engaging in the lives of those who are at the margins and offering horizons of hope (Manchala et al. 2013:42).

\section{CONCLUSION}

This new affirmation aims to provide new concepts and directions for mission. My conviction is that the TTL document provides mission and Missiology with a dialogue partner that reminds the church, and those who practise theology - especially Missiology - that we are together on a journey towards life. The changing landscapes on this journey remind us that the church finds itself in the liminal space between an institution and a community of sent disciples participating in God's mission. The Spirit is the guide, reminding us that we can find the Father's Son among the least and the marginalized - the "shadow stories of the community" (Meylahn 2012:65). It is a time of risk, but also a time filled with the hope and promise of life in all its fullness.

\section{BIBLIOGRAPHY}

BALIA, D. \& KIM, K. 2010. Edinburgh 2010: Volume II. Witnessing to Christ today. Edinburgh 2010 Series. Oxford: Regnum.

\section{Bevans, S.}

2014. "Mission of the Spirit". International Review of Mission 103(1): 30-33.

Bevans, S. \& Schroeder, R. 2004. Constants in context: $A$ theology for mission today. Maryknoll: Orbis Books. 2011. Prophetic dialogue: Reflections on Christian mission today. Maryknoll: Orbis Books.

BILLINGS, J.T. 2010. The Word of God for the people of God: An entryway to the theological interpretation of Scripture. Grand Rapids: Eerdmans [Kindle Edition].

Bosch, D.J.

1979. A spirituality of the road. Scottdale: Herald Press.

1991. Transforming mission. Maryknoll: Orbis Books. 
Butin, P.W.

1995. Revelation, redemption and response. Calvin's trinitarian understanding of the divine-human relationship. Oxford: Oxford University Press.

Cruchley-Jones, P.

2014. "[Un]settled upon and Sent": Mission in the Spirit - A Biblical reflection on “Together towards life". International Review of Mission 103(1):63-70.

DOORNENBAL, R.J.A.

2012. Crossroads: An exploration of the emerging-missional conversation with a special focus on "missional leadership" and its challenges for theological education. Delft: Eburon Academic Publisher.

FLETT, J.

2010. The witness of God: The trinity, missio Dei, Karl Barth, and the nature of Christian community. Grand Rapids: Eerdmans.

HIRSCH, A.

2006. The forgotten ways: Reactivating the missional church. Michigan: Brazos Press.

KeUm, J.

2012. Editorial. International Review of Mission 101(1):1-5.

KeUm, J. (ED.)

2013. Together towards life: Mission and evangelism in changing landscapes. With a practical guide. Geneva: World Council of Churches Publications.

Kıм, K.

2009. Joining in with the Spirit: Connecting world church and local mission. London: Epworth.

2011. Mission's changing landscape: Global flows and Christian movements. International Review of Mission 100(2):244-267.

2013. Editorial. Mission Studies 30(1):3-8.

Kritzinger, J.N.J. \& SAAYman, W.

2011. David J. Bosch: Prophetic integrity, cruciform praxis. Dorpspruit: Cluster.

LAING, M.

2011. The church is the mission: Integrating the IMC with the WCC. International Review of Mission 100(2):216-231.

LANGERAK, A.

2011. A personal tribute to the international review of mission. International Review of Mission 100(2):189-202.

Lausanne Movement, The

2011. The Cape Town Commitment. A confession of faith and a call to action. Proceedings of the 3rd Lausanne congress on world evangelization, Cape Town, South Africa, 16-25 October 2010. [Online.] Retrieved from: http://www. lausanne.org/docs/CapeTownCommitment.pdf [2014, 1 June]. 
LEENE, A.M.J.

2013. Triniteit, antropologie en ecclesiologie: Een kritisch onderzoek naar implicaties van de Godsleer voor de positie van mannen en vrouwen in de kerk. Unpublished PhD. Stellenbosch: University of Stellenbosch.

Matand, B.

2013. A free-wheeling breath of life? Discerning the missio spiritus. International Review of Mission 102(2):137-147.

Manchala, D., Rajkumar, P. \& Prabhakar, D.J.

2013. When margins inform and re-form mission: Dalit experiences as a foundation for mission theology. In: Edinburgh 2010. Volume 13. Foundations of Mission, Edinburgh 2010 Series. Oxford: Regnum.

Matthey, J.

2010. Missional spirituality in the contemporary world. In: V. Mortenson \& A.Ø. Nielsen (eds.), Walk humbly with the Lord: Church and mission engaging plurality (Grand Rapids: Eerdmans), pp. 247-264.

MCKINLEY, R.

2005. Jesus in the margins: Finding God in the places we ignore. Multnomah: Sisters.

MeYLAhn, J.

2012. Church emerging from the cracks: $A$ church in, but not of the World. Stellenbosch: SunPress.

Moltmann, J.

2010. Sun of righteousness, arise! London: SCM.

NeWBigin, L.

1995. The open secret: An introduction to the theology of mission. Grand Rapids: Eerdmans.

Niemandt, C.J.P.

2012. Trends in missional ecclesiology. HTS Teologiese Studies/Theological Studies 68(1):1198.

Niles, D.M.A.

2012. It is time to dance with dragons. International Review of Mission 100(2):268-280.

NoORDT, G.

2013. "So what?" - Dutch responses to the new mission statement. International Review of Mission 102(2):191-198.

Ross, K.R., Nilsson, E.C. \& HewitT, R. 2014. Busan and beyond: Taking forward the new WCC mission affirmation together towards life. International Review of Mission 103(1):3-17. 
SKRESLET, S.H.

2012. Comprehending mission: The questions, methods, themes, problems, and prospects of missiology. Maryknoll: Orbis Books.

TVEIT, O.F.

2013. Foreword. In: World Council of Churches. Resource book WCC $10^{\text {th }}$ Assembly, (Geneva: World Council of Churches Publications), p. vii - ix.

VAN GeLDER, C.

2007. The ministry of the missional church: A community led by the Spirit. Grand Rapids: Baker Academic.

VAN GeLDeR, C. \& DWight, J.Z.

2011. The missional church in perspective: Mapping trends and shaping conversations. Grand Rapids: Baker Academic.

Van Niekerk, A.

2014. The need for ethical quality of life practices. NGTT 55(1):407-424.

WILD-WoOD, E.

2013. Common witness "in Christ": Peregrinations through mission and migration. Mission Studies 30(1):43-63.

Woods, P.

2014. CWM perspective on missional congregations as life-affirming communities. International Review of Mission 103(1):77-81.

World CouncIl of Churches 2013a. WCC 10th Assembly. [Online.] Retrieved from: http://wcc2013.info/en/ news-media/all-news/mission-a-call-to-life-giving-witness [2014, 31 January].

2013b. Resource book WCC 10 ${ }^{\text {th }}$ Assembly, Busan 2013. Geneva: World Council of Churches Publications.

WRIGHT, C.J.H.

2006. The mission of God: Unlocking the Bible's grand narratives. Downers Grove: IVP Academic.

Keywords

Mission policy

World Council of Churches

Missional ecclesiology

Missional leadership

Transformative spirituality

Discernment
Sleutelwoorde

Sendingbeleid

Wêreldraad van Kerke

Missionale ekklesiologie

Missionale leierskap

Transformerende spiritualiteit

Onderskeiding 